\title{
The Physiological Function of Nitrate Reduction in Clostridium perfringens
}

\author{
By S. M. HASAN AND J. B. HALL \\ Department of Microbiology, University of Hawaii, \\ Honolulu, Hawaii 96822, U.S.A.
}

(Received 10 June 1974; revised 3 October 1974)

SUMMARY

Fermentation-balance studies have been carried out on Clostridium perfringens grown in the presence and absence of nitrate in the medium. Nitrate is able to serve as an electron acceptor for these bacteria, permitting increased growth yields over those obtained in its absence. This increase is due to an increase in the proportion of metabolite molecules which can participate in substrate-level phosphorylation reactions when an inorganic acceptor is available. The nitrate reduction can be regarded as a primitive form of anaerobic respiration in these bacteria, since it is clearly coupled to their energy metabolism and is not assimilative in function. We believe that the existence of this kind of energy metabolism in these bacteria has significant evolutionary implications.

\section{INTRODUCTION}

Many bacteria, including a variety of anaerobes, are known to reduce nitrate. In many cases, only trace amounts of this compound are reduced and incorporated. Other bacteria, however, including both strict and facultative anaerobes, reduce far more nitrate than is needed for synthetic reactions. The function of this reduction is best understood for the facultative anaerobes and most textbooks treat nitrate respiration as if it were found only in such bacteria.

A recent theory of the evolution of the prokaryotes suggests that the electron transport chain must have evolved under anaerobic conditions with some acceptor other than free oxygen serving as the terminal oxidant (Hall, 1971, I973). Of the likely candidates, only nitrate has sufficient oxidizing power to permit the development of several phosphateactivating steps in sequence as found in respiratory aerobes and phototrophs today. This hypothesis predicts that nitrate reduction must have been coupled to the energy metabolism of bacteria at a very early stage in their evolution.

Thus, we have been interested in determining whether nitrate reduction in obligate anaerobes is associated with their energy metabolism or serves some other purpose. The studies of Ishimoto \& Egami (I959) and Takahashi, Taniguchi \& Egami (I963) indicate that in some Clostridia nitrate reduction is linked to energy production, but the comparative fermentation balances necessary to answer this question conclusively had not been reported for any of these anaerobes grown in the presence of nitrate. We have attempted to remedy this deficiency. 


\section{METHODS}

Cultures and growth conditions. Clostridium perfringens, ATCC3624, was obtained from the American Type Culture Collection. Stocks of spores were prepared by inoculating actively growing vegetative cells into the sporulation medium described by Ellner (1956). The bacteria were grown on the partially defined medium of Fuchs \& Bonde (1957) throughout the study, but with varying glucose concentrations as indicated for the individual experiments. Growth experiments were carried out in small screw-capped culture tubes containing $5 \mathrm{ml}$ medium. A $0 \cdot \mathrm{I} \mathrm{ml}$ portion of suspension of spores in water was used to inoculate this medium; it was heat-shocked for $10 \mathrm{~min}$ at $75^{\circ} \mathrm{C}$, cooled to room temperature, and incubated at $40{ }^{\circ} \mathrm{C}$. A layer of mineral oil was poured on top of the medium to maintain anaerobic conditions. Growth was followed by reading the absorbancies of the cultures at $600 \mathrm{~nm}$ in a Spectronic 20 colorimeter (Bausch \& Lomb). Each tube was gently agitated to ensure a uniform distribution of bacteria before reading the absorbancy. The absorbancy readings were converted to dry weights when appropriate by reference to a standard curve. Absorbancies above 0.600 were corrected to compensate for the non-linear relationship between bacterial mass and absorbancy reading in this region. Bacteria were harvested by centrifugation at $9000 \mathrm{~g}$ in a Sorvall $\mathrm{RC} 2-\mathrm{B}$ centrifuge.

Assay of fermentation products. Nitrate and nitrite were assayed in culture supernates by the method of Van't Riet, Stouthamer \& Planta (I968). Ammonia was determined by the Conway procedure (Umbreit, Burris \& Stauffer, 1949).

Glucose was determined by means of a Glucostat reagents kit (Worthington Biochemical Corp., Freehold, New Jersey, U.S.A.). Lactic acid was assayed with a Rapid Lactate Stat-Pack reagent kit (Calbiochem, Los Angeles, California, U.S.A.).

Volatile acids were measured by gas-liquid chromatography (Anaerobe Laboratory Manual, 1972) using a Bendix gas chromatograph series I 500 fitted with a flame ionization detector. The volatile acids were extracted into diethyl ether from acidified culture supernate by the method described in the Anaerobe Laboratory Manual (1972). Amounts of each compound were calculated from the area of its peak, by reference to a standard curve for that compound.

Alcohols were also measured by gas chromatography on the same instrument.

Carbon dioxide and hydrogen evolution were measured by conventional manometric techniques (Umbreit et al. 1949). Fermentation balances were calculated according to Wood (I96I).

\section{RESULTS}

\section{Growth rate and growth yields}

When the growth rates of $C$. perfringens on the medium, with and without added nitrate, were compared they were found to be essentially identical (Fig. I), even when the glucose concentrations were varied over a wide range. There was a consistent 30 to 60 min delay in the initiation of exponential growth of the bacteria in the absence of nitrate. Since the cultures were routinely started by inoculating the medium with spore stocks, it is likely that nitrate has an effect on the rate of germination of the spores. Labbe \& Duncan (1970) indicated that nitrite has a stimulatory effect on the germination of Clostridium perfringens, and at the concentrations they found to be effective $(0.5$ to $1.5 \%$, w/v, sodium nitrite) it seems possible that significant traces of nitrate were present.

The molar growth yields of the bacteria grown on the partially defined medium were linearly related to the glucose concentration over the range in which this substrate is limiting, 


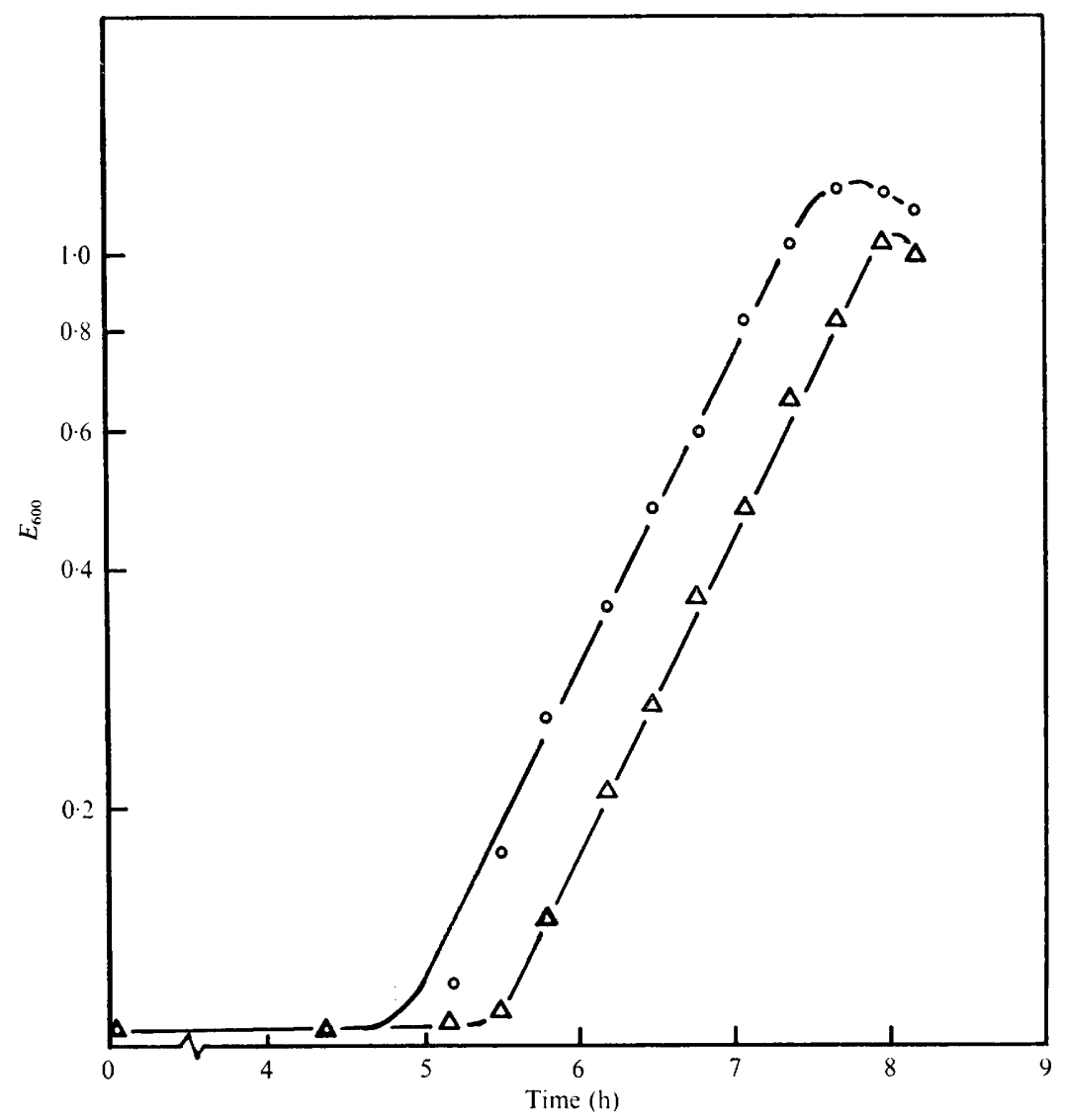

Fig. I. Growth of $C$. perfringens on medium lacking nitrate $(\triangle)$ and on medium containing $3.2 \mu \mathrm{mol}$ nitrate $/ \mathrm{ml}(\bigcirc)$. Growth was measured as $E_{600}$.

and the assays are reasonably accurate. This was true whether nitrate was present or not, but the yields of nitrate-grown cultures were consistently higher at any given glucose concentration than those of cultures grown in the absence of nitrate (Fig. 2). These greater yields were obtained even though the growth rates were the same because the nitrate-grown cultures remained in the exponential growth phase slightly longer than those lacking nitrate (Fig. I) which was probably due to their greater economy in the utilization of substrate. In both cultures, extrapolation of the line relating yields and glucose concentration suggests that growth ceases before glucose concentration reaches zero, indicating that little or no growth will occur in the absence of this energy source despite the abundance of amino acids and other growth factors in this medium. All fermentation balance experiments were carried out with glucose concentrations of between $\mathrm{I} \cdot 8$ and $2 \cdot 2 \mathrm{~g} / \mathrm{l}$, within the range in which this substrate is limiting for growth.

The fate of nitrate in the cultures

Nitrite is deleterious to the growth of $C$. perfringens, but the extent to which it accumulates depends on the initial nitrate concentration. If this is kept sufficiently low, most of the nitrite is further reduced soon after it is formed and little accumulates in the medium to poison the cells. The optimum concentration of nitrate for growth of the bacteria was determined by 


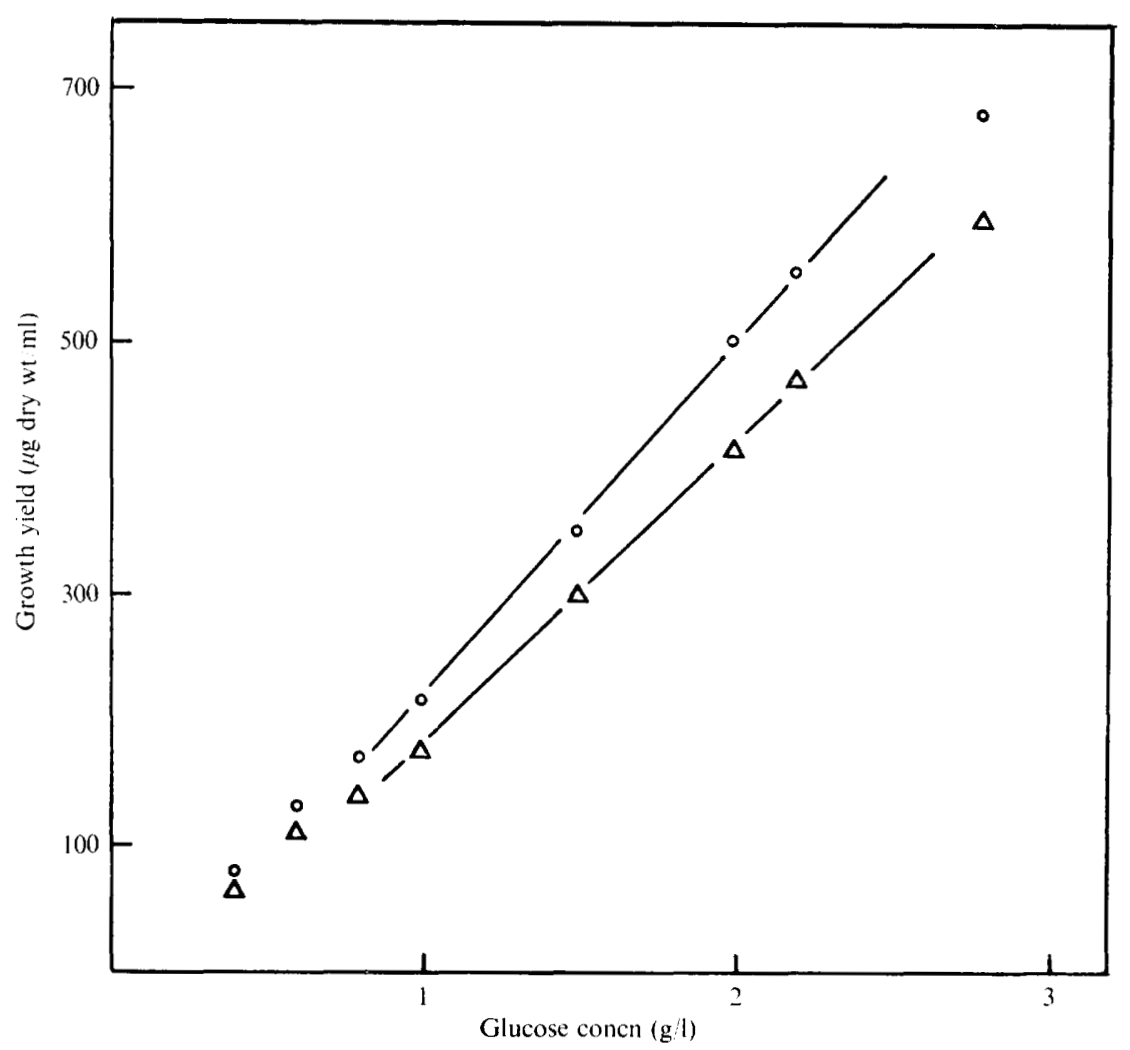

Fig. 2. Growth yields of $C$. perfringens on medium lacking nitrate $(\triangle)$ and on medium containing $3 \cdot 2 \mu \mathrm{mol}$ nitrate $/ \mathrm{ml}(\mathrm{O})$.

measuring the growth yields in the presence of varying nitrate concentrations (Fig. 3). In the fermentation balance studies 3.2 to $3.5 \mu \mathrm{mol} / \mathrm{ml}$ were used. At this level of nitrate, only a transient accumulation of nitrite occurred (Fig. 4) and no inhibition of growth was observed. The medium contained about $19 \mu \mathrm{mol}$ amino acids $/ \mathrm{ml}$, in addition to adenine and various vitamins, and $\mathrm{I}$ gm ammonium chloride $/ \mathrm{l}$ ( $\mathrm{I} 9 \mu \mathrm{mol} / \mathrm{ml}$ ) (Fuchs \& Bonde, I957). Thus, while the $3.2 \mu \mathrm{mol}$ or so of nitrate $/ \mathrm{ml}$ could have supplied the bulk of the nitrogen in the final crop of bacteria, it seems unlikely that it did so.

If little of the nitrate reduced remains as nitrite, what is the normal end product of this reduction? Clostridia have not generally been included among the denitrifiers, and there was no reason to expect that nitrogen gas would be a significant product of their metabolism. Woods (1938) reported that this organism reduced nitrate to ammonia. Ammonia was rather difficult to measure, since the amounts included in the medium were greatly in excess of the amounts that might be produced from nitrate. If ammonium chloride was omitted from the medium, growth rates of the cultures were reduced but it then became possible to measure the amounts of ammonia produced from nitrate. Under these conditions, the ammonia required by the bacteria for growth was supplied by that contaminating the mixture of amino acids added to the medium (see Table I). Ammonia, together with the small amounts of nitrite produced, appeared to account quantitatively for all the nitrate reduced, and we believe, in agreement with Woods (I938), that ammonia is the major reduction product of nitrate dissimilation in this species of bacterium. Production of ammonia has also 


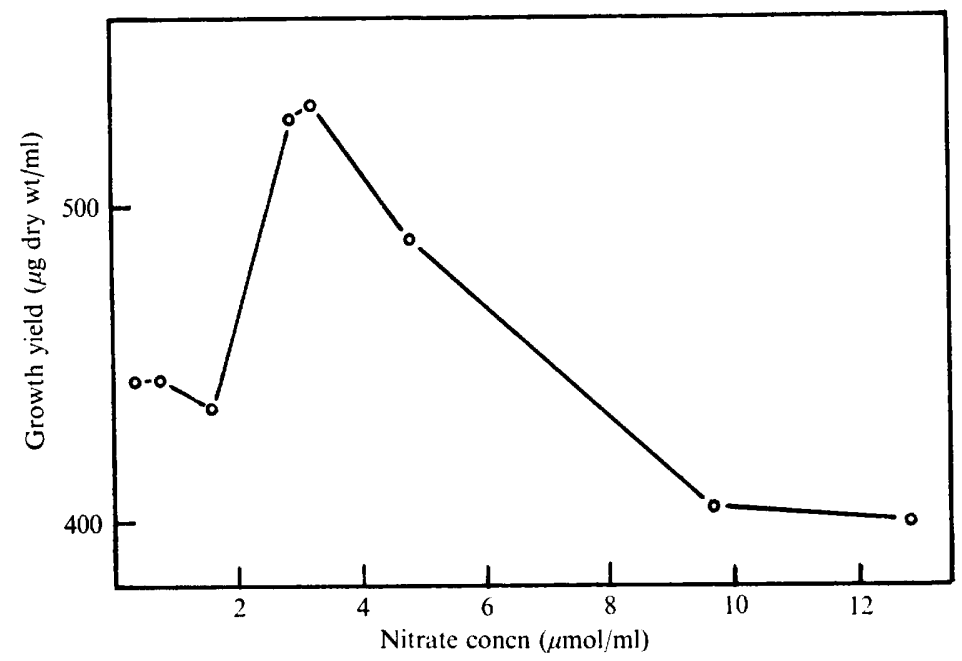

Fig. 3. Growth yields of $C$. perfringens on media containing different concentrations of nitrate.

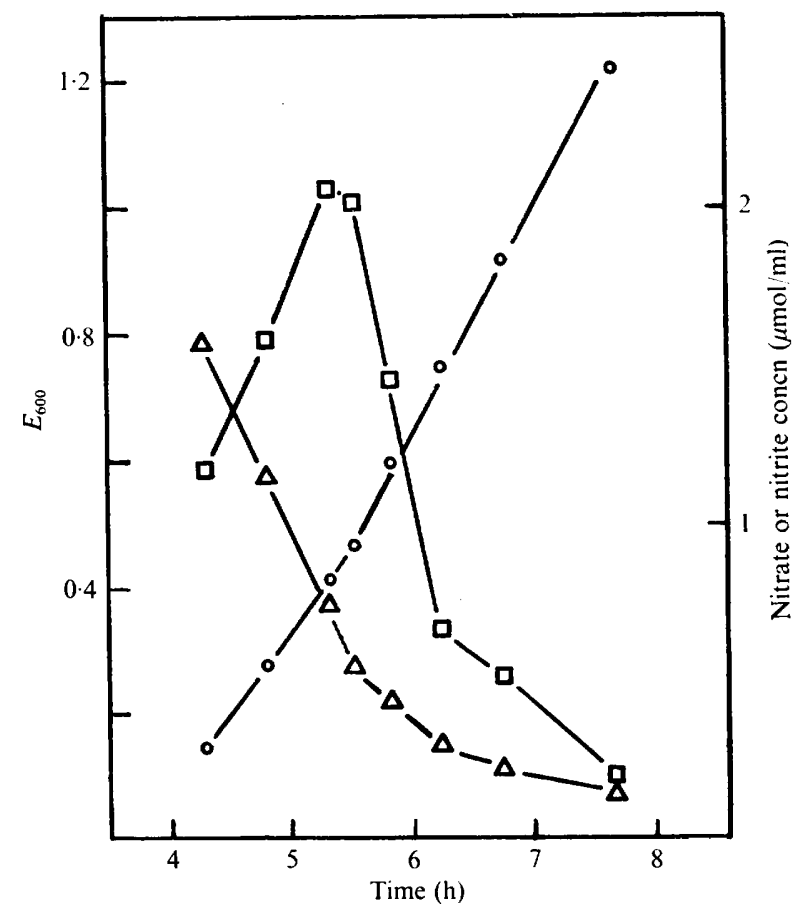

Fig. 4. Growth of $C$. perfringens on medium containing $3 \cdot 2 \mu \mathrm{mol}$ nitrate $/ \mathrm{ml}(\bigcirc)$ and the changes in nitrate $(\triangle)$ and nitrite $(\square)$ concentrations that occur during growth. 
Table I. Inorganic nitrogen balances in cultures grown in the absence of added ammonium salts

Compound
Nitrate added
Nitrate remaining
Nitrate used
Nitrite produced
Initial ammonia in medium
Total ammonia found after bacterial growth
Ammonia produced from nitrate
Nitrate-nitrogen accounted for
Percentage recovered

\begin{tabular}{ccc}
\multicolumn{3}{c}{$\begin{array}{c}\text { Amounts measured } \\
(\mu \mathrm{mol} / \mathrm{ml})\end{array}$} \\
Expt I & Expt 2 & Controls \\
3.2 & 3.2 & 0.00 \\
0.4 & 0.3 & - \\
2.8 & 2.9 & - \\
0.00 & 0.00 & 0.00 \\
3.3 & 3.3 & 3.3 \\
10.5 & 10.1 & $7.2^{*}$ \\
3.3 & 2.9 & - \\
3.7 & 3.2 & - \\
116 & 100 & -
\end{tabular}

* Appreciable ammonia is produced from the amino acids in the medium. Control values to determine the amount of this ammonia are the averages of two determinations.

been reported during nitrate respiration in a facultative anaerobe (Hadjipetrou \& Stouthamer, 1965).

\section{Fermentation balances}

Table 2 gives the data on the fermentation products of $C$. perfringens when grown with and without nitrate. The mass of bacteria obtained per mole of glucose consumed is clearly greater in the presence of nitrate than in its absence. A consideration of the fermentation products reveals why this is so. The utilization of nitrate as an electron acceptor requires a shift in metabolism to produce more of the relatively oxidized organic products compared with the amounts of the reduced compounds. The yield of acetate per mole of glucose used is doubled, while the yields of the more reduced products, ethanol, butyrate and hydrogen, are reduced. The production of lactate and carbon dioxide seem to be little affected. The increase in acetate presumably reflects an increase in ATP synthesis from acetyl phosphate. It is possible to calculate whether or not this increased capacity for substrate level phosphorylation is sufficient to explain the greater growth yields in the presence of nitrate if certain simple assumptions are made: a net yield of I mol ATP from each mol 3-carbon unit occurs during glycolysis, and one more is produced from acyl phosphate for each mole acetate or butyrate formed. Thus, each mole acetate appearing as a final product represents the synthesis of $2 \mathrm{~mol} \mathrm{ATP}$; each butyrate, $3 \mathrm{~mol}$; each lactate, I mol; and each ethanol, I mol (Mickelson, 1972). The resulting calculations of ATP produced in the presence and absence of nitrate, and the molar yield coefficient with respect to ATP $\left(Y_{\mathrm{ATP}}\right)$ calculated from these figures are given in Table 3 . The yields in the presence of nitrate can be accounted for entirely by the increased acyl phosphate production.

The assay procedures would have detected propanol, succinate, and propionate (after methylation, where appropriate) had any been present in the medium, but none was found. Formate would only have been detected if substantial amounts had been produced. The ratio of one carbon to two carbon compounds indicates that no significant amounts could have been produced, however. Pyruvate was detected, but the amounts (generally $0 \cdot 0$ I to $0.02 \mathrm{~mol} / \mathrm{mol}$ glucose) were so small that this compound was neglected in calculating the fermentation balances. Traces of butanol were detected in the culture lacking nitrate, but the amounts were negligible. 


\section{Table 2. Fermentation of glucose in the presence or absence of nitrate} by $C$. perfringens

Each value is the average of two determinations, except for the gas values, each of which required a pair of flasks for the assay. Values in parentheses were calculated by supplying the missing analytical values from the average values ( $\mathrm{mol} / \mathrm{mol}$ glucose) found in the relevant parallel experiments. The ratio of the relatively oxidized organic compounds to reduced products $(O / R$ index $)$ was calculated by assuming that all of the nitrate consumed was converted to nitrite (measured) and ammonia (the remainder).

\begin{tabular}{|c|c|c|c|c|c|c|}
\hline \multirow{2}{*}{ Determination $\quad \ldots$} & \multicolumn{3}{|c|}{ With nitrate } & \multicolumn{3}{|c|}{ Without nitrate } \\
\hline & I & 2 & 3 & $\mathbf{I}$ & 2 & 3 \\
\hline Nitrate used $(\mu \mathrm{mol} / \mathrm{ml})$ & $3 \cdot 49$ & 一 & 一 & - & - & - \\
\hline Glucose used $(\mu \mathrm{mol} / \mathrm{ml})$ & II $\cdot 0$ & II $\cdot 0$ & $9 \cdot 7$ & 10.9 & II $\cdot 0$ & $I 2 \cdot I$ \\
\hline $\begin{array}{l}\text { Products }(\mu \mathrm{mol} / \mathrm{ml}) \\
\text { Acetic acid } \\
\text { Butyric acid } \\
\text { Lactic acid } \\
\text { Ethanol } \\
\text { Carbon dioxide } \\
\text { Hydrogen } \\
\text { Nitrite }\end{array}$ & $\begin{array}{c}\mathrm{II} \cdot 3 \\
2 \cdot 0 \\
3 \cdot 0 \\
2 \cdot 4 \\
- \\
- \\
0.03\end{array}$ & $\begin{array}{r}\text { I } 2 \cdot 2 \\
\text { I } \cdot 7 \\
2 \cdot 6 \\
3 \cdot 3 \\
18 \cdot 9 \\
15 \cdot 2 \\
-\end{array}$ & $\begin{array}{r}\text { II } \cdot 5 \\
\text { I.5 } \\
- \\
2 \cdot 3 \\
\text { I } 8 \cdot I \\
\text { I } 4 \cdot 4 \\
-\end{array}$ & $\begin{array}{l}4 \cdot 8 \\
3 \cdot 5 \\
3 \cdot 3 \\
4 \cdot 7 \\
- \\
-\end{array}$ & $\begin{array}{r}6 \cdot 1 \\
2 \cdot 9 \\
2 \cdot 9 \\
6 \cdot 0 \\
19 \cdot 7 \\
19.8 \\
-\end{array}$ & $\begin{array}{r}6 \cdot 8 \\
3 \cdot 4 \\
6 \cdot 4 \\
22 \cdot 2 \\
21 \cdot 6 \\
-.\end{array}$ \\
\hline $\begin{array}{l}\text { Products (mol/mol glucose) } \\
\text { Acetic acid } \\
\text { Butyric acid } \\
\text { Lactic acid } \\
\text { Ethanol } \\
\text { Carbon dioxide } \\
\text { Hydrogen } \\
\text { Nitrite }\end{array}$ & $\begin{array}{l}\mathrm{I} .03 \\
0.18 \\
0.27 \\
0.22 \\
- \\
- \\
0.00\end{array}$ & $\begin{array}{l}I \cdot I \mathrm{I} \\
0 . \mathrm{I} 5 \\
0.24 \\
0.30 \\
\mathrm{I} \cdot 72 \\
\mathrm{I} \cdot 38 \\
-\end{array}$ & $\begin{array}{l}\text { I.I } 5 \\
0.15 \\
- \\
0.24 \\
0.87 \\
I .49 \\
-\end{array}$ & $\begin{array}{l}0.44 \\
0.32 \\
0.30 \\
0.43 \\
- \\
- \\
-\end{array}$ & $\begin{array}{l}0.55 \\
0.26 \\
0.26 \\
0.55 \\
\mathrm{I} .79 \\
\mathrm{I} .80 \\
-\end{array}$ & $\begin{array}{l}0.56 \\
0.28 \\
- \\
0.53 \\
1.83 \\
1.78 \\
-\end{array}$ \\
\hline Dry weight of bacteria $(\mu \mathrm{g} / \mathrm{ml})$ & 495 & - & 一 & 420 & 一 & 一 \\
\hline $\begin{array}{l}\text { Gram dry wt } / \mathrm{mol} \text { glucose } \\
\text { Carbon recovered (mol } / \mathrm{mol} \\
\text { glucose) }\end{array}$ & $\begin{array}{l}45 \cdot 0 \\
(5 \cdot 83)\end{array}$ & $5 \cdot 86$ & $\overline{(6 \cdot 06)}$ & $\begin{array}{l}38 \cdot 3 \\
(5 \cdot 73)\end{array}$ & - & $\begin{array}{c}- \\
(6 \cdot 00)\end{array}$ \\
\hline Carbon recovered $(\%)$ & $(97)$ & 98 & (IOI) & $(96)$ & 97 & $(100)$ \\
\hline $\mathrm{O} / \mathrm{R}$ index & $(\mathrm{I} \cdot 03)$ & $(\mathrm{I} \cdot 07)$ & $(\mathrm{I} \cdot 07)$ & $(I \cdot I 0)$ & $1 \cdot 05$ & $\mathrm{I} \cdot 08$ \\
\hline $\mathrm{C}-\mathrm{I} / \mathrm{C}-2$ ratio & $(I \cdot I 2)$ & $\mathrm{I} \cdot \mathrm{O}$ & $(1 \cdot I)$ & $(\mathrm{I} \cdot 20)$ & $\mathbf{I} \cdot \mathbf{I}$ & $(\mathrm{I} \cdot \mathrm{I})$ \\
\hline
\end{tabular}

Table 3. Molar yield coefficients of C. perfringens grown in the presence or absence of nitrate

The number of moles of ATP produced per mole of glucose utilized were calculated from the fermentation products as described in the text. The data used were from the duplicate experiments whose averages are given in columns I, Table 2 . The $Y_{\mathrm{ATP}}$ values (in $\mathrm{g}$ dry wt bacteria produced $/ \mathrm{mol}$ ATP generated) were obtained by dividing the observed yields from Table 2 by this calculated ATP yield.

\begin{tabular}{|c|c|c|c|}
\hline & $\begin{array}{l}\text { ATP produced } \\
\text { (mol/mol glucose } \\
\text { utilized) }\end{array}$ & $\begin{array}{c}\text { Cell yield } \\
\text { (g/mol glucose } \\
\text { utilized) }\end{array}$ & $Y_{\mathrm{ATP}}$ \\
\hline \multicolumn{4}{|l|}{ Nitrate } \\
\hline Expt I & $3 \cdot 04$ & $45^{\circ} \mathrm{O}$ & $14 \cdot 8$ \\
\hline Expt 2 & 3.13 & $45^{\circ} 0$ & $14 \cdot 4$ \\
\hline Average & 3.08 & $45^{\circ} 0$ & $14 \cdot 6$ \\
\hline \multicolumn{4}{|l|}{ No nitrate } \\
\hline Expt I & $2 \cdot 5 \mathrm{I}$ & $39 \cdot 0$ & 15.5 \\
\hline Expt 2 & $2 \cdot 65$ & $37 \cdot 7$ & 14.2 \\
\hline Average & $2 \cdot 58$ & $38 \cdot 3$ & $\mathrm{I} 4 \cdot 8$ \\
\hline
\end{tabular}




\section{DISCUSSION}

In view of the observation that $C$. perfringens has an absolute requirement for a variety of amino acids (eleven according to Fuchs \& Bonde, I957), as well as ammonia (Fuchs \& Bonde, I 957), and can grow quite well on these in the absence of any major additional source of nitrogen, it does not seem plausible that it retains a vigorous nitrate reductase system in order to supply a requirement for reduced nitrogen compounds. The conclusion seems inescapable that nitrate reduction in these organisms is dissimilatory in character, and if it is not retained because of its value to the energy-generating metabolism of the bacterium, it must be serving some unspecified, and mysterious, alternative function.

The fermentation balances presented in this paper demonstrate that the utilization of reducing potential for the reduction of nitrate permits the net oxidation of the organic substrate in such a way that additional substrate-level phosphorylation is made possible. These observations eliminate the possibility that nitrate reduction was occurring solely at the expense of the production of hydrogen or by diverting electrons from some other end product in a way that had no influence on energy-generating mechanisms. Since nitrate reduction is clearly not assimilative in nature in these bacteria and does appear to be associated with energy metabolism, it would be of interest to know whether this process is of sufficient value to the bacteria to account for its retention in this species and (assuming that it serves an analogous role in other bacteria) its wide-spread occurrence in other anaerobes.

Consideration of the data in Tables 2 and 3 shows that the increased yield of ATP per mole of glucose consumed, and the corresponding increase in bacterial mass, in the presence of nitrate, over the yields produced by bacteria grown in its absence, were of the order of $\mathrm{I} 6$ to $20 \%$. This is not a trivial margin, particularly to a free-living anaerobe existing by the inefficient processes of fermentation in environments in which the abundance of fermentable substrates must often be limiting for growth. We believe that the development of a system like this was a decided advantage to the first organisms that possessed it, and provided the vital initial step toward the evolution of respiratory systems in general (Hall, I97I, 1973). As Stanier (1970) points out, referring to selection for the evolution of new modes of energy metabolism, 'Such selection appears to have been a major factor in the evolution of prokaryotes, as shown by their unrivalled contemporary diversity with respect to mechanisms of energy generation'.

Whether the form of nitrate reduction linked to energy production reported here should be considered a form of nitrate respiration depends on the definition one prefers. Egami refers to the process as 'nitrate fermentation' (Ishimoto \& Egami, I959; Takahashi et al. I963) and Decker, Jungermann \& Thauer (I970) would restrict the term 'respiration' to those processes in which phosphate activation is linked to electron transport. On the other hand, many authors prefer a simple definition in which the nature of the electron acceptor is the prime criterion, with processes utilizing organic acceptors being considered fermentations, and those utilizing inorganic acceptors, respiration (see Stanier, Doudoroff \& Adelberg, I 970 , for a typical text-book example). We prefer the simplicity of the latter definition. Using it, the form of nitrate reduction reported here would become the simplest and most primitive type of nitrate respiration.

We thank Mr T. Wilkinson and his colleagues at the Virginia Polytechnic Institute Anaerobe Laboratory for supplying us with bacterial cultures and information about the many useful techniques that they have developed for working with anaerobes. This work was supported by funds of the Department of Microbiology of the University of Hawaii. 


\section{REFERENCES}

Anaerobe Laboratory Manual (1972), pp. i I3-II4. Edited by L. V. Holdeman and W. E. C. Moore. Blacksburg, Virginia: Virginia Polytechnic Institute and State University Anaerobe Laboratory.

Decker, K., JungermanN, K. \& Thauer, R. K. (1970). Energy production in anaerobic organisms. Angewandte Chemie (International edition in English) 9, $138-158$.

ELLNER, P. D. (1956). A medium promoting rapid quantitative sporulation in Clostridium perfringens. Journal of Bacteriology 7r, 495-496.

Fuchs, A. R. \& Bonde, G. J. (1957). The nutritional requirements of Clostridium perfringens. Journal of General Microbiology 16, 317-329.

Hadjipetrou, L. P. \& Stouthamer, A. H. (I 965). Energy production during nitrate respiration by Aerobacter aerogenes. Journal of General Microbiology 38, 29-34.

HALL, J. B. (197I). Evolution of the prokaryotes. Journal of Theoretical Biology 30, 429-453.

HALL, J. B. (1973). The occurrence of nitrate on the early earth and its role in the evolution of the prokaryotes. Space Life Sciences 4, 204-213.

Ishimoto, M. \& EGAMI, F. (I959). Meaning of nitrate and sulfate reduction in the process of metabolic evolution. In Proceedings of the First International Symposium on the Origin of Life on Earth (1957), pp. 555-56I. Edited by F. Clark and R. L. M. Synge for the International Union of Biochemistry. New York: Pergamon Press.

LABBE, R. G. \& DUNCAN, C. L. (1970). Growth from spores of Clostridium perfringens in the presence of sodium nitrite. Applied Microbiology I9, 353-359.

MickeLson, M. N. (1972). Glucose degradation, molar growth yields, and evidence for oxidative phosphorylation in Streptococcus agalactiae. Journal of Bacteriology rog, 96-105.

Stanier, R. Y. (1970). Some aspects of the biology of cells and their possible evolutionary significance. Symposia of the Society for General Microbiology 20, I-38.

Stanier, R. Y., Doudoroff, M. \& Adelberg, E. A. (1970). The Microbial World, 3rd edn, pp. 177-178. Englewood Cliffs, New Jersey: Prentice-Hall.

TAKahashi, H., TANiguchi, S. \& Egami, F. (1963). Inorganic nitrogen compounds: distribution and metabolism. In Comparative Biochemistry, pp. 9I-202. Edited by M. Florkin and H. S. Mason. New York: Academic Press.

Umbreit, W. W., Burris, R. H. \& Stauffer, J. F. (1949). Manometric Techniques and Tissue Metabolism, 2nd edn, pp. 17-77, I56-158. Minneapolis, Minnesota: Burgess.

Van't Riet, J., Stouthamer, A. H. \& Planta, R. J. (I968). Regulation of nitrate assimilation and nitrate respiration in Aerobacter aerogenes. Journal of Bacteriology 96, I455-I464.

Wood, W. A. (1961). Fermentation of carbohydrates and related compounds. In The Bacteria, vol. 2, pp. 59-I 49. Edited by I. C. Gunsalus and R. Y. Stanier. New York: Academic Press.

Woons, D. D. (1938). The reduction of nitrate to ammonia by Clostridium welchii. Biochemical Journal 32, 2000-2012. 